\title{
Conditional Accounting Conservatism Lessens the Cost of Capital: Evidence from Non-Financial Sector of Pakistan
}

\author{
Naveed Razzaq *
}

\begin{abstract}
The intention of this research article is to explore the accounting conservatism association with the cost of capital in Pakistani firms. For this examination, data collected from annual reports of 142 firms registered in Pakistan Stock Exchanges (PSX) for the period 2006 to 2011. This paper calculates the cost of capital by employing OJ-Model (2005) and accounting conservatism by using renowned Basu (1997) model. Current paper found a significant negative association of irregular measurement of earnings (bad news or c-score) and the cost of capital, which infers that conservative reporting in Pakistani firms reduces the cost of capital. Furthermore, this study also concludes by finding significant results that risk premium and return on assets have directly proportion relationship with the cost of capital. In extent, present study increases the literature in same vein of study and interest of accounting conservatism in financial reporting and academic research in Pakistan.
\end{abstract}

Keywords: Conservatism, reduces, cost of capital, Pakistan.

\section{Introduction}

The importance of conservatism (realization of loss than profit) has been increased from last couple of decades and accounting academic researchers, standards setters and regulators had debated accounting conservatism and its expected economic consequences. After long discussion, Financial Accounting Standards Board (FASB) and International accounting Standards Board (IASB) decided that conservatism will not more be a part of accounting standards. Conversely, some educational researchers demonstrated that accounting conservatism is a significant indicator of reporting quality. Furthermore, Watts (2003); Grambovas, Giner, and Christodoulou (2006) stated that conservatism is still live in our accounting practices and increasing from last 30 years. The accounting literature indicates that accounting conservatism has been broadly investigated and studied. Recent educational worker concentrated to elaborate conservatism existence and determinants such as (Basu, 1997; Watts, 2003). However, contemporary research is focusing on economics consequences of accounting conservatism approach in accounting practices.

Accounting literature drew numerous studies of conservatism association with cost of capital, investment efficiency, corporate governance and accounting quality. Lara, Osma, and Penalva (2009a, 2009b) showed positive relationship of conservatism and investment efficiency and negative relation with cost of capital. Furthermore, accounting conser-

\footnotetext{
*Foreign Expert (Lecturer), School of Economics and Management, Xinyu University, China.

E-mail: naveed.razzaq@hotmail.com
} 
vatism acts alternative of voluntary disclosure (Gietzmann and Trombetta, 2003), which is useful for end users that's why financiers demand for conservative reporting. Furthermore, some researchers also observed that conservative approach in financial reporting diminishes the agency problem between borrowers and lenders. In addition, conservatism reduces the chance of manger manipulation and limits managers opportunist behaviour (Guay \& Verrecchia, 2018). Accounting conservatism literatures also resolve agency problem between manger and investor. In other hand, conservatism reporting encourages the managers to divulge all information, which possibly will cause to reduce the cost of debt and equity.

This paper reckons the accounting conservatism existence in Pakistan and connection of conservative financial reporting and the cost of capital. It claims that timely appreciation of losses over profit in financial reporting lowers the cost of capital. Similarly, former researchers also examined the relation of accounting conservatism and the cost of capital, and stated that timely appreciation of bad news in incomes (earnings) reduces the cost of capital. Such as, this voluntary disclosure or conservative reporting diminishes the cost of capital is investigated and reported by Francis and Martin (2010); Li (2014); Lambert, Leuz, and Verrecchia (2007). In same vein, it also considers that accounting conservatism may have similar influence on cost of capital in the context of Pakistani firms.

Present paper contributes to the accounting literature and conservatism work on economic consequences. First contribution of this study, it will be pioneer to explore the conservative financial reporting and the cost of capital relation in the context of Pakistan. Second, it uses the different methods to compute the cost of capital to infer this study. This study finding and results are consistent with former research.

\section{Literature Review}

Researcher's investigated and reported the existence of conservatism in accounting system as well as discretely projected their empirical study results about conservatism. Accounting conservatism has important characteristics and has been used for a long time in financial reporting quality (Watts, 2003; Francis \& Martin, 2010). Sterling $(1970,256)$ documented that "rates conservatism as the most influential principle of valuation in accounting". The extreme reporting of negative earnings shows greater return propensity as compare to the extreme positive earnings (Brooks and Buckmaster, 1976). Hayn in 1995 stated that "Firms with positive earnings have larger short window and long window ERCs (earnings response coefficient) than firms with negative earnings". Furthermore, Bliss (1924) predicted a rule of conventional approach of accountant conservatism as "anticipate no profit but anticipate all the losses". In line with this literature about conservatism, researchers also depicted the existence of conservatism for decades and increasing use of conservatism in our system with the passage of time despite criticism, in other words, accounting conservatism has influenced accounting practices from many years. Basu (1997); Givoly and Hayn (2000) mostly discussed that conservatism as reporting net asset expectation less than long run market value. After sometime then Givoly and Hayn (2000) measured the accounting conservatism with accumulative negative non-operating 
accruals.

Basu (1997) further interpreted and investigate the conservatism in accounting. He introduced a contemporary way of estimation. His model is well-known to estimate the existence of conservatism in firms. Educational workers are using his model to reckon accounting conservatism. Furthermore, Khan and Watts (2009) introduced an advance form of accounting measurement on the basis of Basu (1997)'s irregular timely measurement of earnings of accounting conservatism. They introduced the G-Score (gains as good news) and C-Score (losses as bad news) measurement of conditional accounting conservatism. Present study also follows Khan and Watts (2009) to calculate the accounting conservatism in Pakistan and this method is renowned and widely used by researchers to evaluate conservatism.

Li (2014) scrutinized that conservative approach in financial practices decreases the cost of equity capital, additional, his work reckoned a negative relationships among conditional conservatism and the cost of capital in those countries where legal systems are stronger. Current study reviewed several studies from latest and prior literature. Its goal is to enhance the diverse investigative work about the affiliation of conservative financial reporting and the cost of capital. As per Francis and Martin (2010); Lambert et al. (2007) reported that the cost of capital may diminish by increasing voluntarily disclosure in financial statements. Though, Gietzmann and Trombetta (2003) illustrated that accounting conservatism approach practices a substitute for voluntary disclosure. Bognoli $\&$ Watts (2005) examined and stated that conservative financial reporting in accounting impairs the cost of capital with same effect. In additional work about manager's opportunist actions, (Guay \& Verrecchia, 2018) stated that accounting conservatism lessen the managerial opportunistic attitude and constrains manager's from manipulating earnings. Moreover, they found that conservative reporting may reduce the cost of capital by reducing the concession rate. Furthermore, the contemporary work showed that conservatism increases the quality of information and enriches the information in discolours (Chen \& Huang, 2007). However, their work controvert with other research.

\section{Research Design}

This paper describes the model under the examination of conservatism relationship with cost of capital. Current study model arrangement is founded on prior research papers on similar lines of renowned researchers; they investigated conditional conservatism and the cost of capital relationship and conservative accounting economic consequences (Francis \& Martin, 2010; Lara et al., 2009a; Li, 2014).

\section{Hypothesis Development}

Present study scrutinises the conditional accounting conservatism timelines information recognition (profits and losses) association with cost of capital. Timely recording of losses than gains is decreasing the cost of capital. Thus, it hypotheses that conservative financial reporting reasons to diminish the cost of capital. Gigler et al. (2009) examined that 
conservatism lessens the cost of equity and debt capital. Prior academic reported that conditional accounting conservatism is caused to lowers the cost of capital researchers (Francis \& Martin, 2010). Most recent researchers studied that accounting conservatism has influenced on the cost of capital and their outcomes showed that accounting conservatism decreases the cost of capital (Lambert et al., 2007; Lara et al., 2009b; Razzaq, Rui, \& Donghua, 2016). Therefore, current paper advances a postulate that conservative financial reporting lessens the cost of capital for the companies in emerging market. This document is surmising a negative relationship among them.

Hypothesis: Conservative financial reporting (conditional accounting conservatism) lessens the cost of capital.

\section{Methodology}

To investigate accounting conservatism effects on the cost of capital. Propose study used annual reports of 142 firms to obtain accounting information. The information is dug out from listed companies' annual reports. Security and Exchange Commission of Pakistan (SECP) is a regulatory body which controls all listed firms in Pakistan. In data sample all companies are non-financial with time period 2006 to 2011. All firms are registered in Pakistan Stock Exchange (PSX); this document only included non-financial firms because financial firm's organizational structure, accounting practices and investment environment are different. Proposed study data consists of 852 obs. However, by eliminating incomplete variables observations by matching and balancing data year and industry, obtained 822 observations to estimate. Table 1 explains all variables detail.

\begin{tabular}{ll} 
Table 1 & \\
Variables Explanation \\
\hline Variables & Explanations \\
\hline CONS & "Conditional accounting conservatism, C-score (bad news negative earnings)" \\
CCap & "Cost of Equity Capital evaluated from OJ- Model (2005)" \\
DPF & Dividend pay-out is calculated total dividend paid / total number of shares \\
SIZE & Firm size is logarithm of total assets \\
LR & Leverage of firms gained as total liability scaled by total assets \\
ROA & Return on assets is evaluated net income scaled by total assets \\
RPR & Risk premium gained Fixed assets scaled by aggregate assets \\
LIQ & Liquidity of the firms (1/no. of days after the year end * daily return / volume of transaction) \\
MB & Market to book ratio (year-end share price * total number of shares) / book value of the equity \\
\hline
\end{tabular}

\section{Measurement of Accounting Conservatism and the Cost of Capital}

Accounting conservatism become an important issue and debatable topic for educational researchers in recent years. Two renowned methods to calculate conservatism 1) asymmetric timeliness of earnings (Basu, 1997) and accrual based method (Givoly \& Hayn, 2000). However, these conservatism measure methods are based on accounting practices of firm performance. This study calculates the conservatism by employing Basu (1997) model, however further introduced by Khan and Watts (2009). Basu (1997) examined earnings which are related with negative return (Bad news) and positive return (good 
news). Constantly, it accomplished the calculation of the succeeding standard of this method and scrutinized the timely increasing factor that improved the conditional conservatism. These description and estimation help to figure out the occurrence of conservatism in practices of accounting system of Pakistani companies, which additional led to evaluate accounting conservatism (CONS) with cost of capital (calculated by OJ-Method) using control variables.

The conditional accounting conservatism has negative relation with cost of capital. The conservative financial reporting lowers the cost of capital by decreasing dividend pay-out. Most recent researches by Wu (2011); Li (2014); Razzaq and Rui (2018) also investigated the impact of accounting conservatism on cost of capital of the firms, their researches claimed that conservative financial reporting (conditional accounting conservatism) impairs the cost of capital. Present work portrays a following model.

$$
\begin{array}{r}
C \operatorname{Cap}_{i, t}=\alpha+\beta_{1} C O N S_{i t}+\beta_{2} L I Q_{i t}+\beta_{3} L R_{i t}+\beta_{4} R O A_{i t}+\beta_{5} S I Z E_{i t}+\beta_{6} P R i t+\beta_{7} D P F_{i t}+ \\
\beta_{8} M B_{i t}+\epsilon_{i, t}
\end{array}
$$

Where, all variables have been explained above (see Table 1 for detail).

\section{Results}

\section{Descriptive Analysis}

This paper descriptive statistics are given in Table 2 shows all variables descriptive statistics used in this research. This table represents the no. obs., mean, median, standard deviation (Std. Dev.), percentage (25\% and $75 \%)$, maximum and minimum values of variables. Conditional conservatism (CONS) values of mean, median and Std. Div. are -3.318, 0.3294 and 57.283, respectively. The range of CONS from minimum of -423.1 to maximum 168.5 and values of 25 and 75 percentages are -27.426 and 27.426, respectively. Conservatism values are different because researchers calculated conservatism with different methods that are difficult to compare conditional conservatism (CONS) values with former researchers. The mean, median and Std. Div. values of cost of capital (CCap) are 240.45, 213.5 and 211.056, respectively. The cost of capital (CCap), ranges from minimum

\begin{tabular}{|c|c|c|c|c|c|c|c|c|}
\hline Variables & No. Obs. & Mean & Median & Std. Div. & P25 & Min & P75 & Max \\
\hline CONS & 851 & -3.318 & 0.3294 & 57.283 & -27.426 & -1423.1 & 27.426 & 168.5 \\
\hline CCap & 858 & 240.47 & 213.5 & 211.05 & 2 & 1 & 426.5 & 639 \\
\hline LR & 852 & 0.7661 & 0.690616 & 0.7515 & 0.5197 & 0.02912 & 0.7971 & 9.1304 \\
\hline LIQ & 852 & 422.5 & 422.5 & 243.07 & 212.5 & 243.1 & 634.5 & 838 \\
\hline ROA & 852 & 2.8034 & 1.415 & 13.3177 & -4.2 & -46.73 & 7.93 & 86.53 \\
\hline LR & 852 & 0.5813 & 0.6043 & 0.20489 & 0.4363 & 0 & 0.7351 & 0.9727 \\
\hline SIZE & 852 & 14.688 & 14.643 & 1.6114 & 0.0058 & 10.36 & 0.0595 & 19.38 \\
\hline DPF & 823 & 402174.5 & 0 & 28852 & 0 & 0 & 26640 & $4.09 \mathrm{E}-07$ \\
\hline MB & 852 & 2.9678 & 0.3581 & 51.745 & 0.8824 & 0.004 & 1.0602 & 45.03 \\
\hline
\end{tabular}
of 1 and maximum is 639 and $25 \%$ value is 2 and $75 \%$ value is 426.5 . 
Furthermore, spearman correlation analysis results shows that paper employed variables are not highly associated with each other which show elimination of possibility of a multicollinearity problem among variables. In adding, it tested variance inflation factor (VIF) to sense multicollinearity in the model. It found VIF value 1.14 less than 10. Consequently, VIF test presents that there is no multicollinearity problem in the model.

\section{Regression Analysis}

Table 3 presents the results of regression analysis of the cost of capital and conditional conservatism. As it claims that conditional accounting conservatism and cost of capital have negative relationship; this negative association indicates that conservatism decreases the cost of capital.

\begin{tabular}{|c|c|c|}
\hline Independent variables & Sign & Coefficients (t-value) \\
\hline CONS & $(-)$ & $-0.497(-4.11)^{* * *}$ \\
\hline LIQ & $(+)$ & $-0.012(-0.37)$ \\
\hline LR & $(+)$ & $0.003(0.10)$ \\
\hline ROA & $(-)$ & $1.901(3.03)^{* * *}$ \\
\hline SIZE & $(-)$ & $10.12(2.15)^{* *}$ \\
\hline LR & $(+)$ & $223.1(6.10)^{* * *}$ \\
\hline DPF & $(-)$ & $-0.000012(-4.53)^{* * *}$ \\
\hline MB & $(-)$ & $-.058(-0.43)$ \\
\hline Year fixed effect & & Yes \\
\hline Intercept & & $-33.68(-0.44)$ \\
\hline No. Obs. & & 822 \\
\hline R-Square & & $0.091(9.1 \%)$ \\
\hline
\end{tabular}

Present paper enhances the literature of same vein of study in emerging market such as Pakistan. It conjectured that conservative financial reporting lowers the cost of capital in Pakistani firms. Therefore, it was expecting -ve affiliation among them, Table 4 presents that conditional conservatism (CONS) negatively significant (coeff. $=-0.497$, $\mathrm{t}$-value $=$ 4.11 ) at $1 \%$ level. This finding corroborates our prediction and hypothesis that accounting conservatism diminishes the cost of capital. Accordance with previous research capital (Francis \& Martin, 2010; Guay \& Verrecchia, 2018), conservatism reduces the cost of Capital. Furthermore, this paper did not find leverage and liquidity significant relationship with cost of capital. However, It found positive significant relation with return on assets (coeff. $=1.901$, $\mathrm{t}$-value $=3.03)(\mathrm{ROA})$ which is vice versa of our expectation, firm size (coeff. $=10.12$, $\mathrm{t}$-value $=2.15)($ SIZE $)$ and risk premium $($ coeff. $=223.1$, $\mathrm{t}$-value $=6.10)(\mathrm{LR})$ at $1 \%, 5 \%$ and $1 \%$ level, respectively. Return on assets (ROA) and firm size (SIZE) significant positive association with cost of capital and may cause to increase the cost of capital. These results predict that good returns or performance and large firm size increase the cost of capital for the firms in Pakistan. Further, It found a direct proportionality between risk premium and cost of capital which infers that greater the risk premium then higher the cost of capital. More, those companies are having greater cost of capital might be 
performing well by getting more risk premium as return. So, this paper results are corroborating study hypothesis that conservatism decreases the cost of capital. This work also explains that dividend pay-out diminishes the cost of capital.

\section{Conclusion}

Accounting conservatism is an integral characteristic of financial reporting. Former accounting literature has documented that accounting conservatism longstanding and effective accounting principle. Furthermore, researchers investigated conditional conservatism relation with cost of capital and reported that conservatism lessens the cost of capital. Similar line with prior studies, it analysed conditional accounting conservatism and the cost of capital; Present article outcomes shows that conservatism decreases the cost of capital in the context of Pakistan. This research will be first study which inspected the association of conditional accounting conservatism with cost of capital by conducting data sample from Pakistan.

Researchers lavishly investigated and scrutinizing accounting conservatism effects on accounting practices and economics consequences. As a result, conservatism stills a contemporary and debateable topic for academic researchers. This research is contributing many ways such as, First, this study will be first to investigate conservative approach in accounting system of Pakistani companies and it association with cost of capital association in the context of Pakistan. Second, it sheds a light on conservatism existence and reveals international accounting standards adoption level (conservative reporting infers reporting quality) in Pakistan. Furthermore, this study enhances the accounting literature in same vein of study, encourages and provides new research horizon to domestic educational researchers. Furthermore, it finds conditional accounting conservatism economic consequences that conservative financial reporting in accounting practices of Pakistani firms lowers the cost of capital, beneficial for firms to outsource funds at lower interest rates. However, this paper unable to evidence and explain in detail that firm's performance increases by decreasing cost of capital. Overall, it successfully depicts that timely recognition of loss over profit lowers the cost of capital. In addition, this study may unable to discuss some aspects such as agency conflict, how conservative approach in accounting system diminishes the cost of capital. This study abandons these issues for future research with new manners of data samples and variables. 


\section{References}

Basu, S. (1997). The conservatism principle and the asymmetric timeliness of earnings. Journal of Accounting and Economics, 24(1), 3-37.

Chen, X., \& Huang, D. (2007). Corporate governance and accounting conservatism-an empirical study based onlisting corporation. Securities Market Herald, 3, 10-17.

Francis, J. R., \& Martin, X. (2010). Acquisition profitability and timely loss recognition. Journal of Accounting and Economics, 49(1-2), 161-178.

Givoly, D., \& Hayn, C. (2000). The changing time-series properties of earnings, cash flows and accruals: Has financial reporting become more conservative? Journal of Accounting and Economics, 29(3), 287-320.

Grambovas, C. A., Giner, B., \& Christodoulou, D. (2006). Earnings conservatism: Panel data evidence from the European Union and the United States. Abacus, 42(3-4), 354378.

Guay, W. R., \& Verrecchia, R. E. (2018). Conservative disclosure. Journal of Financial Reporting, 3(1), 73-92.

Khan, M., \& Watts, R. L. (2009). Estimation and empirical properties of a firm-year measure of accounting conservatism. Journal of Accounting and Economics, 48(2-3), 132150.

Lambert, R., Leuz, C., \& Verrecchia, R. E. (2007). Accounting information, disclosure, and the cost of capital. Journal of Accounting Research, 45(2), 385-420.

Lara, J. M. G., Osma, B. G., \& Penalva, F. (2009a). Accounting conservatism and corporate governance. Review of Accounting Studies, 14(1), 161-201.

Lara, J. M. G., Osma, B. G., \& Penalva, F. (2009b). Conditional conservatism and firm investment efficiency.

Li, X. (2014). Accounting conditional conservatism and the cost of capital: An international analysis. Journal of Business Finance \& Accounting, 42(5/6), 555-582.

Razzaq, N., \& Rui, Z. (2018). Does conditional conservatism affect the cost of capital? evidence from China. Journal of Finance and Economics Research, 3(1), 57-70.

Razzaq, N., Rui, Z., \& Donghua, Z. (2016). Accounting conservatism alleviates firm's investment efficiency: An evidence from China. International Journal of Business and Economics Research., 5(4), 85-94.

Watts, R. L. (2003). Conservatism in accounting part I: Explanations and implications. Accounting Horizons, 17(3), 207-221.

$\mathrm{Wu}, \mathrm{Y}$. L. (2011). Research on the relationship between controlling shareholder and accounting conservatism in China. Applied Mechanics and Materials, 65, 579-584. 